US investment

\section{Universities and South Africa}

Washington

THIS spring has brought to many US college campuses demonstrations, reminiscent of the 1960s, against apartheid in South Africa. With the demonstrations has come a reconsideration of an old issue: should universities invest in companies that do business in South Africa?

According to several recent surveys, fewer than a dozen universities have completely divested themselves of holdings in such companies. And even as pressure mounts to divest, a new study by the Investor Responsibility Research Center, an organization founded 13 years ago to provide institutional investors with information on the ethical behaviour of corporations, may stiffen the resolve of those university boards that have resisted so far: according to the report, "divestment will have a detrimental effect over the long term on portfolio performance".

Most of the hundred or so universities that have taken some action on investments in South Africa, mostly in response to protests in the early 1970s, have adopted policies of partial, selective divestment, usually selling off stock in companies that fail to adhere to the so-called Sullivan principles. These rules, developed by Reverend Leon Sullivan of Philadelphia, a member of the General Motors board of directors, prescribe basic fair employment practices for companies operating in South Africa. The universities that have opted for partial divestment argue that a selective policy is the best method of influencing corporate behaviour; with across-the-board divestment, influence is lost.

Those calling for total divestment now say that this selective policy simply has not produced results. According to a recent survey by the American Council on Education (ACE), only about 100 of the 350 US companies operating in South Africa adhere to the Sullivan principles; and in any case there is no evidence that other foreign companies or South African companies have been influenced by the example of these 100. Bishop Desmond Tutu, who won the Nobel peace prize for his stand against apartheid, has called for a more stringent set of principles: companies in South Africa should recognize black labour unions, invest in black education and training, and should freely hire blacks without regard for the country's restrictive laws governing the movement and residence of the $\mathbf{2 4}$ million South African blacks.

The most militant protests this spring have taken place at Columbia Unjversity and the University of California at Berkeley, both of which already have policies of partial divestment. Students have occupied buildings and there have been a number of arrests.

And while both of those universities have agreed to reconsider their policies, others

are being more outspoken in their belief that the chief responsibility of university financial administrators is to make money for the university. Derek Bok, president of Harvard, which has maintained a selective divestment policy since 1981 , spoke for many when he said recently: "Despite our revulsion toward apartheid, the fact remains that Harvard's resources were entrusted to us for academic purposes and not as a means for demonstrating our opposition to apartheid or to other manifest injustices and evils around the world." The
Boston University

Brown University

City College of New York

Columbia University

Dartmouth College

Harvard University

Michigan State University

Ohio State University

Rutgers

Swarthmore College

Tufts University

University of California, Berkeley

University of Michigan

University of Pennsylvania

University of Wisconsin

Yale University
Washington

HoFrmaNN-La Roche employees laid off earlier this year in what the company described as an austerity measure have

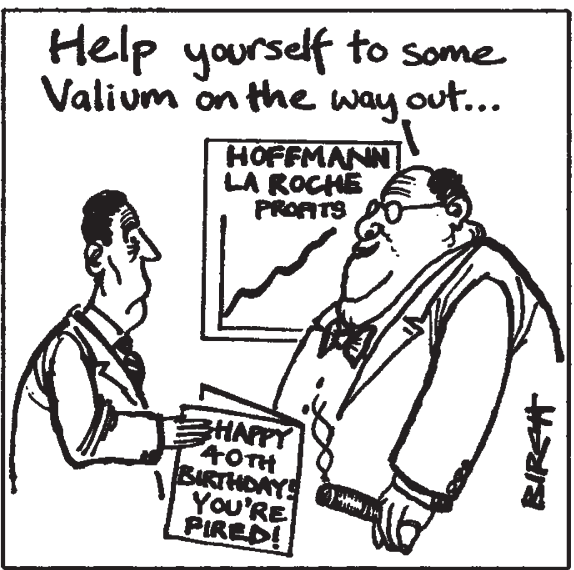

sued, alleging age discrimination. The suit, so far joined by 250 laid-off workers all over age 40, accuses Roche of pursuing a deliberate policy of singling out older employees for dismissal. More than 1,000

ACE survey noted that even among those universities choosing total divestment, the justification was that colleges "should not benefit from corporate practices that cause social injury"; they rejected the notion that they were taking a political stand.

US investment in South Africa is estimated at $\$ 14,000$ million. About one-third of the companies on Standard \& Poor's 500-company stock index do business in South Africa.

Besides the efforts on campus, a number of states and municipalities have ordered divestment. A bill now before the US Congress would ban bank loans and computer sales to the South African government.

Stephen Budiansky

Major universities that have divested stock in companies operating in South Africa

$\begin{array}{lcc}\text { Policy } & \begin{array}{c}\text { Value of } \\ \text { stock divested } \\ \text { \$6.6 million }\end{array} & \begin{array}{c}\text { Year action } \\ \text { taken }\end{array} \\ \text { Partial } & 4.6 & 1979 \\ \text { Partial } & 7.1 & 1984 \\ \text { Total } & 2.7 & 1984 \\ \text { Partial } & 2.0 & 1979 \\ \text { Partial } & 50.9 & 1985 \\ \text { Partial } & 1.0 & 1981 \\ & 7.2 & 1985 \\ \text { Total } & 0.3 & 1979 \\ \text { Partial } & 7.0 & 1978 \\ \text { Partial } & 2.2 & 1985 \\ \text { Partial } & 0.1 & 1981 \\ \text { Partial } & 4.0 & 1979 \\ \text { Partial } & 41.0 & 1979 \\ \text { Partial } & 0.8 & 1983 \\ \text { Partial } & 11.0 & 1983 \\ \text { Total } & 1.6 & 1978 \\ \text { Partial } & 4.1 & 1979 \\ & & 1984\end{array}$

Universities that have adopted a policy of total divestment have sold all holdings in companies that do business in South Africa. Partial divestment refers to a policy of selling stock in companies that have failed to adhere to the Sullivan principles or other standards of conduct or that refuse to provide information. Source: American Committee on Africa.

\title{
Age discrimination alleged
}

employees were dismissed in a move to save $\$ 50$ million a year for the next five years. Lawyers for the plaintiffs say that as many as 600 of these employees could be eligible to join the suit, which they hope to have certified as a class action.

The suit also alleges that the company's policies governing promotions, transfers and assignments favour younger workers at the expense of those over $\mathbf{4 0}$.

Federal law prohibits age discrimination in employment. Companies that violate the act are liable for back pay, compensation for loss of future earning power, attorneys' fees, and, if "wilful" violation of the act can be shown, double damages.

Leonard Flamm, an attorney for the plaintiff, says that most of the layofis occurred at Nutley and Belvidere, New Jersey.

Hoffmann-La Roche says that it intends to defend all such lawsuits brought against it and maintains that all decisions to terminate employment were "nondiscriminatory". No date has been set for preliminary hearings.
Stephen Budiansky 